\title{
Effect of Nitrogen and Periphyton Extract on the Growth of Nostoc sphaericum in Cultures
}

\author{
Itzel Becerra-Absalón, ${ }^{1}$ Thomas Buhse, ${ }^{2}$ Carlos Polanco, ${ }^{2,3,4}$ and Rosaluz Tavera ${ }^{1}$ \\ ${ }^{1}$ Departamento de Ecología y Recursos Naturales, Facultad de Ciencias, Universidad Nacional Autónoma de \\ México. Ciudedad Universitaria, 04510 México, DF, Mexico \\ ${ }^{2}$ Centro de Investigaciones Químicas, Universidad Autónoma del Estado de Morelos, Avenida Universidad 1001, \\ 62209 Cuernavaca, MOR, Mexico \\ ${ }^{3}$ Departamento de Matemáticas, Facultad de Ciencias, Universidad Nacional Autónoma de \\ México. Ciudedad Universitaria, 04510 México, DF, Mexico \\ ${ }^{4}$ Subdirección de Epidemiología Hospitalaria y Control de Calidad de la Atención Médica, Instituto Nacional de \\ Ciencias Médicas y Nutrición Salvador Zubirán, Vasco de Quiroga 15, Piso 4, Colonia, Sección XVI, 14000 Mexico, DF, Mexico
}

Correspondence should be addressed to Rosaluz Tavera,r_tavera@ciencias.unam.mx

Received 9 August 2012; Accepted 1 September 2012

Academic Editors: A. Chappelka, D. Pimentel, and R. Zhu

Copyright ( 2012 Itzel Becerra-Absalón et al. This is an open access article distributed under the Creative Commons Attribution License, which permits unrestricted use, distribution, and reproduction in any medium, provided the original work is properly cited.

\begin{abstract}
Nostoc sphaericum shows marked growth differences in two Mexican wetland ecosystems consisting of rain forest and tropical deciduous forest, respectively. The amount of nitrogen and periphyton extract dominated by other Cyanoprokaryota had been identified as the most obvious differences between these two ecosystems. We studied the impact of these variables on the physiology and morphology of N. sphaericum. that is, the chlorophyll-a content of the thalli and the changes in the size of the trichomes as well as the cell division rate. Our results combined with a statistical verification indicate that the cell division rate of $N$. sphaericum with solid media is neither stimulated by nitrogen nor by accompanying cyanoprokaryotes and therefore is assumed to have no impact on the thalli observed in situ. However, these two variables are affecting the size of both the trichomes and the thalli, thus suggested to cause the observed growth differences between the two wetlands.
\end{abstract}

\section{Introduction}

Previous studies in the El Edén Ecological Reserve (EER) revealed that the periphyton is able to store large quantities of nutrients [1]. These findings suggested that the periphyton could be a potential fertilizer for widespread use like other organic fertilizers as, for example, chicken litter manure or compost [2]. Greenhouse experiments showed an outstanding concentration of nutrients in periphyton [3], and most of the periphyton doses that were applied to tomato and maize plants were as efficient as-or sometimes even superior to-modern organic fertilizers such as ammonium sulphate. It was also shown that periphyton acts as a natural source of micronutrients in the ecosystem that improves the indigenous arbuscular mycorrhizal symbiosis [2-4].

As illustrated in Figure 1(b), the intense periphyton production in these wetlands covers the entire substrate.
However, the growth is the result of a long-time process as these wetlands are pristine and ancient ecosystems [5]. According to several observations [6], the periphyton recovery rate remains low once it has been removed. This underlines the necessity to study the growth characteristics of this life form before considering the idea of exploiting it as a fertilizer.

The periphyton biofilm attached to the EER soil is mainly composed of Cyanoprokaryota species such as the Nostocales Nostoc sphaericum Vaucher ex Bornet \& Flahault, Tolypothrix sp., Stigonema spp., and Petalonema sp. as well as the Oscillatoriales Geitlerinema spp. and Leptolyngbya spp. [1]. A notable difference in the N. sphaericum growth was observed for two distinct wetland ecosystems of the EER: one situated in a rainforest with an intermittent water column during floods and the other in a tropical deciduous forest with a continuous water column during the flood. 


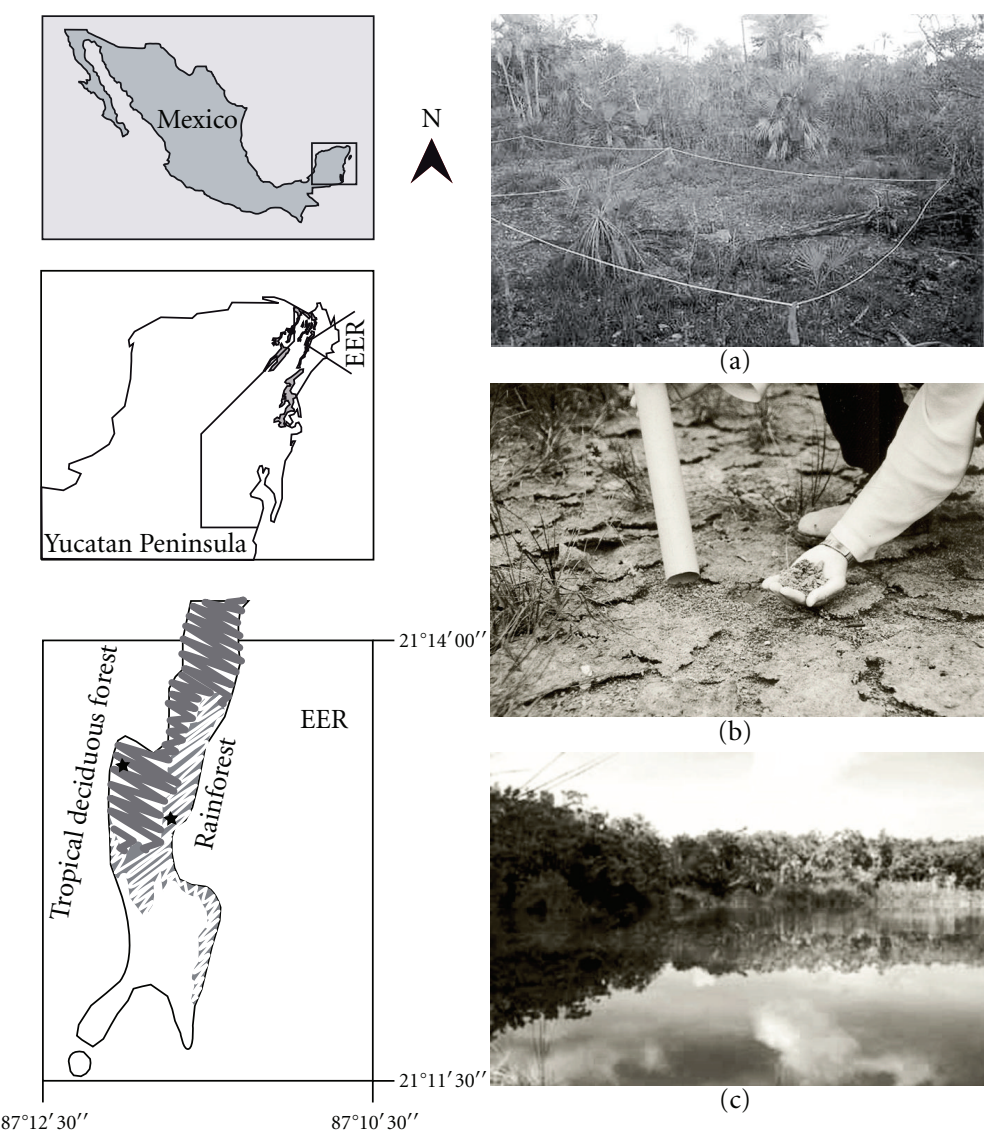

FIGURE 1: The El Edén ecological reserve (EER) located in the state of Quintana Roo, northeast of the Yucatan peninsula, Mexico. The stars in the EER scheme indicate collection sites in the rainforest (a) and in the tropical deciduous forest (c). (b) Shows the periphyton biofilms over the entire substrate of the wetland rainforest.

Independent of the potential use of periphyton as a fertilizer, the growth difference suggests that $N$. sphaericum could be a key species to identify the possible causes that modulate the development of the periphyton in the wetland.

$N$. sphaericum is plainly observed in the rainforest towards the end of the flooding season with scattered patches of $\sim 4 \mathrm{~cm}^{-2}$ and filaments (trichomes) regularly with a density of $10,000 \mathrm{~cm}^{-2}$ and a length of $60-80 \mu \mathrm{m}$. In contrast, in some canopy-gap areas of the tropical deciduous forest, the biofilm of the periphyton is mainly integrated by N. sphaericum. This species grows on the substrate forming individual patches of varying size, from 0.5 to $2.0 \mathrm{~m}^{2}$. The trichome density is generally twice of the rainforest region and with 100-200 $\mu \mathrm{m}$ significantly larger sized. In this periphyton, no other Cyanoprokaryota develop although eukaryotic algae are present among some other components $[1,7]$.

In the rainforest, the annual average of the nitrogen $(\mathrm{SD}$ $=0.0042)$ and phosphorus $(\mathrm{SD}=0.023)$ content in the soil was $0.007 \mathrm{~g} \mathrm{~kg}^{-1}$ and $0.036 \mathrm{~g} \mathrm{~kg}^{-1}$, respectively, while in the tropical deciduous forest was $0.001 \mathrm{~g} \mathrm{~kg}^{-1}$ and $0.0033 \mathrm{~g} \mathrm{~kg}^{-1}$ $[1,3]$. It seems clear that the amount of nitrogen in the rainforest substrate can be higher than in the tropical deciduous forest. It is remarkable that despite the differences in the way N. sphaericum develops, the life cycle is similar in both locations, including the suppression of the aseriate phase that only occurs in cultures without nitrogen [8]. Filaments in culture enter the aseriate stage as usual in the genus, through cell divisions that occur at various angles and that depart from the transverse plane of the filament [9].

The above observations do not provide any information about a relationship between the nutrient concentrations, the presence of Cyanoprokaryota that sometimes accompany $N$. sphaericum and the observed growth difference in the two wetlands. Therefore, using populations of the two ecosystems, we studied the life cycle under laboratory conditions as a first approximation [8] and then expanded the laboratory experiments by testing different combinations of conditions such as nitrogen in the substrate and the presence of other Cyanoprokaryota, which appear to be related to N. sphaericum in the field. The study was based on observations in cultures of ten weeks.

\section{Materials and Methods}

2.1. Ecosystems and Periphyton. The vegetation, soil, hydrogeology, and geomorphology of the Yucatan peninsula in Mexico has been extensively studied [4, 5, 10-12]. The peninsula is characterized by a calcareous substrate (karst) as well as by wetlands such as the El Edén Ecological Reserve (EER). It offers ideal conditions for the growth of periphyton 
(Figure 1) that is mainly composed of cyanoprokaryotes and probably favoured by the alkalinity of the limestone substrate $[13,14]$.

The growth of N. sphaericum in the EER is located at two sites with different vegetation profiles: a rainforest dominated by Haematoxylon campechianum L. with an intermittent water column and a tropical deciduous forest with a continuous water column from August to November. The water temperature fluctuates during the diurnal cycle between 18 and $30^{\circ} \mathrm{C}[1]$. In the rest of the year the wetland remains dry, and the substrate reaches temperatures up to $42^{\circ} \mathrm{C}$ under the biofilm of periphyton [6].

\subsection{Sample Collection and Material Preparation. In Novem-} ber 2002, samples of N. sphaericum were collected at random over particular areas (Figure 1(a)) from each of the two ecosystems and isolated in culture. As in the tropical deciduous forest periphyton community is composed primarily of $N$. sphaericum, we selected only this material to perform the further experiments in cultures under a controlled environment using a plant grow chamber and setting the temperature at $25^{\circ} \mathrm{C}$, irradiation at $28 \mu \mathrm{E} \mathrm{m}^{-2} \mathrm{~s}^{-2}$, and the photoperiod at 12/12.

We obtained clone cultures free of bacteria by reseeding the cultures on agar Blue-Green medium or BG medium, according to the list of media cultures from the literature [15], using in each reseeding a glass handle to distribute the seed cells.

To compare the growth between the thalli, we macerated the full growth produced in several Petri dishes, measuring 15 of these growths every week for 10 weeks. The estimation was made by extracting chlorophyll- $a$ measured by in vitro fluorometry (Turner fluorometer AU-10) by the 445 method [16]. The extraction was completed by dissolving the macerate in $10 \mathrm{~mL}$ of $90 \%$ acetone and leaving it for a period of action of 6-12 hours $\left(4^{\circ} \mathrm{C}\right)$ and then after centrifugation to obtain in a $10 \mathrm{~mL}$ fluorometer cell the full amount extracted from each thallus. Chlorophyll- $a$ units (micrograms per litre) correspond to the direct reading of the cell, according to the method used. All subsequent experiments to assess the growth of $N$. sphaericum with different concentrations of nitrogen and periphyton extract were based on cultivated material 8, 9 and 10 weeks of age, which was identified as the stabilization period of growth in culture [17].

\subsection{Variance Normality and Equality and Statistical Methods} (ANOVA and MANOVA). Random samples were taken from the cultures and the cell and thallus normality was verified (Table 1, entry a). The correlation evaluation of the studied samples required a symmetric matrix of variance covariance verification (Table 1, entry b). In the following stages for the MANOVA analysis the length/width relation (Table 1, entry c) as well as the chlorophyll $a$ amount (Table 1, entry d) were evaluated by several statistical methods.

The ANOVA and MANOVA analyses were performed in SPSS 17.0. The general linear model procedure followed the statistical model for repeated measures. For the analysis, the between-subject factors were the three nitrogen conditions,
TABLE 1: Statistical or analytical methods used to verify experimental results.

\begin{tabular}{|c|c|c|}
\hline Entry & Hypothesis & Method \\
\hline a & $\begin{array}{l}\text { Cells and thalli normality } \\
\text { size }\end{array}$ & Lilliefors test \\
\hline $\mathrm{b}$ & $\begin{array}{l}\text { Equality of error } \\
\text { variances }\end{array}$ & Levene test \\
\hline c & $\begin{array}{l}\text { Length/width correlation } \\
\text { on each of the three solid } \\
\text { media }\end{array}$ & $\begin{array}{l}\text { Pillai's Trace, Wilks' Lambda, } \\
\text { Hotelling's Trace, Roy's } \\
\text { Largest Root with Bonferroni } \\
\text { correction, Mauchly's test, } \\
\text { Levene's test, Tukey's test, and } \\
\text { Games-Howell's test }\end{array}$ \\
\hline d & $\begin{array}{l}\text { Chlorophyll- } a \\
\text { correlation on each of the } \\
\text { three solid media }\end{array}$ & $\begin{array}{l}\text { Pillai's Trace, Wilks'Lambda, } \\
\text { Hotelling's Trace, Roy's } \\
\text { Largest Root with Bonferroni } \\
\text { correction, Mauchly's test, } \\
\text { Levene's test, Tukey's test, and } \\
\text { Games-Howell's test }\end{array}$ \\
\hline
\end{tabular}

and the within-subject factors or repeated measures were the periphyton extract conditions. Normality and homogeneity of variance of size of cells $(N=450)$ and biomass of thalli $(N=135)$ data were analyzed through the KolmogorovSmirnov by the Lilliefors test. Multivariate analyses used the default four statistics testing the ratio of the sum of squares for a hypothesis and the sum of squares for error, that is, Pillai's Trace, Wilks' Lambda, Hotelling's Trace and Roy's Largest Root; the W of Mauchly statistic being used as a test for sphericity. The Levene's statistic was used for homogeneity tests of variance-covariance matrixes. For multiple comparisons, the critical levels and confidence intervals were adjusted by the Bonferroni correction. A Tukey test and a Games-Howell test were used to verify that assuming equal or unequal variances did not change the interpretation. Once multiple comparisons (Post hoc tests) indicated if a tested factor (the concentrations of nitrogen) interactively had an effect on the other tested factor, (the periphyton extract) the effects of the interaction was represented by profile graphs for the growth of thalli (biomass as chlorophyll- $a$ ) and trichome cells (length and width). The profile graphs (Figures 5 and 6) confirmed such interaction and suggested what kind of interaction was detected because they visually contrast the tested hypotheses through the estimated marginal means (EMMs).

\subsubsection{Solid Media Design and Experimental Approach. The} experimental conditions for the cultivation combined several types of media cultures presented in Table 2. The experiments combined three nitrogen conditions. The first condition was prepared without nitrogen, known in the literature as Blue-Green eleven-zero medium $\left(\mathrm{BG}-11_{0}\right)$ [15], which was considered here as the free nitrogen condition. The second condition was prepared according to the known medium called Blue-Green eleven (BG-11) [18], which was considered here as the excessive concentration of nitrogen $\left(1.5 \mathrm{gl}^{-1} \mathrm{NaNO}_{3}\right)$. The third condition was prepared with a stoichiometric balance of nitrogen phosphorus $[19,20]$, 
TABLE 2: Culture conditions for treatments and replicates of the experiment. The cultures were established during 10 weeks for a total of 135 Petri dishes inoculated with N. sphaericum.

\begin{tabular}{lccc}
\hline & $\begin{array}{c}\text { Solid medium free of nitrogen and } \\
\text { free of, or combined with, } \\
\text { periphyton extract }\end{array}$ & $\begin{array}{c}\text { Solid medium with excessive } \\
\text { nitrogen content and free of, or } \\
\text { combined with, periphyton extract. }\end{array}$ & $\begin{array}{c}\text { Solid medium moderated in } \\
\text { nitrogen content and free of, or } \\
\text { combined with, periphyton extract }\end{array}$ \\
\hline 45 Petri dishes & $\mathrm{BG}-11_{0}+\mathrm{PE}_{0}$ & $\mathrm{BG}-11+\mathrm{PE}_{0}$ & $\mathrm{BG}_{-11_{16: 1}+\mathrm{PE}_{0}}$ \\
45 Petri dishes & $\mathrm{BG}-11_{0}+\mathrm{PE}_{25}$ & $\mathrm{BG}-11+\mathrm{PE}_{25}$ & $\mathrm{BG}-11_{16: 1}+\mathrm{PE}_{25}$ \\
45 Petri dishes & $\mathrm{BG}-11_{0}+\mathrm{PE}_{50}$ & $\mathrm{BG}-11+\mathrm{PE}_{50}$ & $\mathrm{BG}-11_{16: 1}+\mathrm{PE}_{50}$ \\
\hline
\end{tabular}

dictated by the concentration measured in situ in the EER, containing $0.52 \mathrm{~g} \mathrm{l}^{-1} \mathrm{NaNO}_{3}$ and $32.5 \mathrm{~g} \mathrm{l}^{-1}$ of $\mathrm{K}_{2} \mathrm{HPO}_{4}$ stock solution. This medium was considered here as the moderate concentration of nitrogen that we call Blue-Green eleven $16: 1,\left(\mathrm{BG}-11_{16: 1}\right)$.

These nitrogen conditions were combined with two periphyton extract conditions (Table 2) called Periphyton Extract (PE). The extract was prepared by macerating $20 \mathrm{~g}$ of natural periphyton biofilm collected in the rainforest. The sterilization of the extract was performed by filtration in a $47 \mathrm{~mm}$ Sterifil Millipore system using nitrocellulose filters (GSWP, $0.22 \mu \mathrm{m}$ ). The extract was prepared in three forms: $50 \%$ per litre dilution $\left(\mathrm{PE}_{50}\right), 25 \%$ per litre dilution $\left(\mathrm{PE}_{25}\right)$, and distilled water containing no periphyton $\left(\mathrm{PE}_{0}\right)$. These solutions were used to dissolve the agar to solid media with or without nitrogen if required under the experimental conditions. We recognized $\mathrm{PE}_{50}$ as the condition of oversupplied extract and $\mathrm{PE}_{25}$ as the condition of limited extract. $\mathrm{PE}_{0}$ was the periphyton-free condition. From the bacteria-free cultures, 15-cell trichomes (average length) were transferred to each of the 45 Petri dishes containing these combined conditions as given in Table 2.

2.4. Growth of Trichomes and Cell Division Change Rate. The trichomes growth was detected by randomly selecting several Petri dish cultures from week 10 and measuring 50 cells from different trichomes. The cell width and length were determined by a microscope. The change in the cell division rate TC was calculated from (1) for each solid media as follows:

$$
T C=\left(\frac{N C}{N T}\right) \times 100
$$

where $N C$ is the cell number in the division process and NT is the total cell amount in 100 trichomes.

2.5. Growth of Thalli. The thallus growth was determined as chlorophyll- $a$ values in each Petri dish with the following procedure.

The chlorophyll- $a$ was extracted randomly from 5 Petri dishes of the week 8 and measured from the full growth. This was done for each culture condition on solid medium given in Table 2. The determination of chlorophyll- $a$ was processed also during the weeks 9 and 10. These three weeks were previously recognized as the time when the cultures reached the stabilization phase (Figure 2).

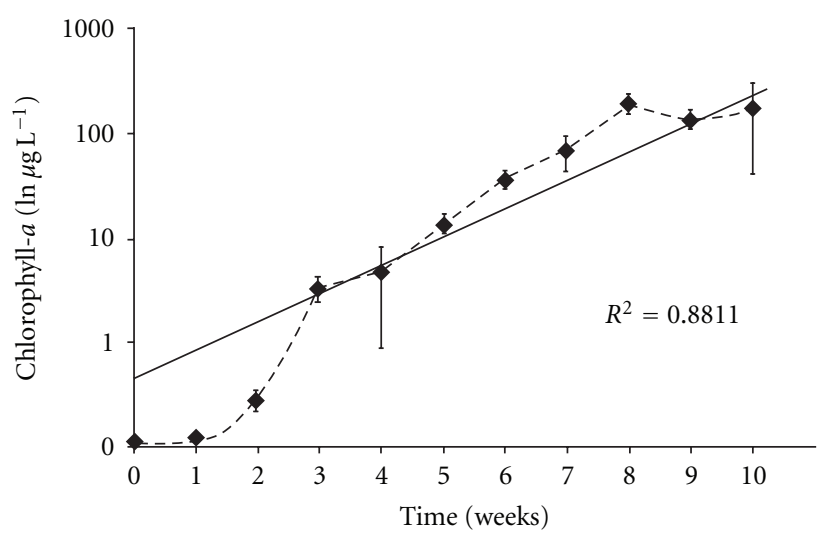

FIGURE 2: Chlorophyll- $a$ as a function of weekly macerated thalli of N. sphaericum.

\section{Results}

3.1. Stabilization of Growth in Culture. The exponential phase of the growth and the period of its stabilization are shown in Figure 2. The stabilization stage was determined between the weeks 8 and 10 matching the stabilization period of the chlorophyll- $a$ amount of $N$. sphaericum measured in these cultures. The growth differences recorded in this study can be identified under a microscope (Figure 3) and are consistent in replicates. According to the statistical analysis, the effect of the studied variables was reliable using these three-week-old cultures.

3.2. Cell Division Change Rate of N. Sphaericum in Culture. The cell division change rate showed no correlation $\left(R^{2}=\right.$ $0.013, P$ value $>0.05$ ) with the size of the cells though it was observed that the division change rate was more active in the absence of nitrogen and periphyton (BG-11 $1_{0}+\mathrm{PE}_{0}$ ) (Table 1c, Figure 4).

3.3. Cell Growth of N. Sphaericum. The presence of periphyton, as periphyton-nitrogen interaction, was significant ( $P$ value $=0.0005)$ for the growth of the thalli, and both the length and width of cells were significantly different $(P$ value $=0.0005$ ) between growing or not with periphyton and between growing with limited $\left(\mathrm{PE}_{25}\right)$ or oversupplied $\left(\mathrm{PE}_{50}\right)$ periphyton. As shown in Figure 5, the cell length correlated $(P$ value $=0.0005)$ with the free-periphyton extract and concentration of nitrogen: BG-11 $1_{0}+\mathrm{PE}_{0}$ and BG-11 $16: 1+$ $\mathrm{PE}_{0}$, but there was no correlation $(P$ value $>0.05)$ with the 


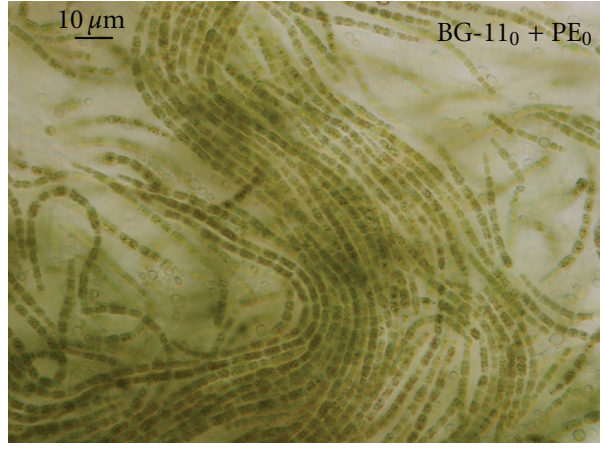

(a)

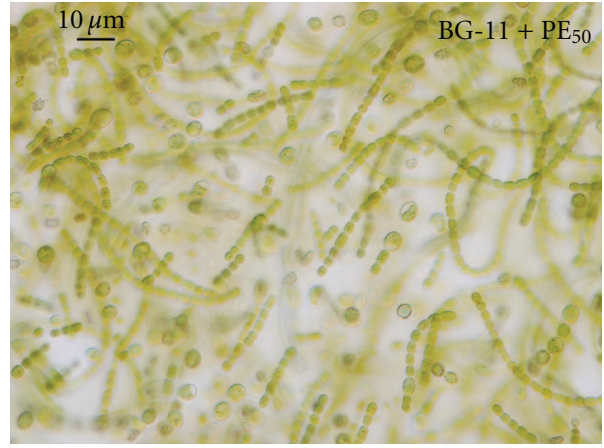

(b)

Figure 3: Trichomes of N. sphaericum nine weeks old in culture without nitrogen and periphyton extract (a) and in medium with excessive nitrogen combined with oversupplied periphyton extract (b).

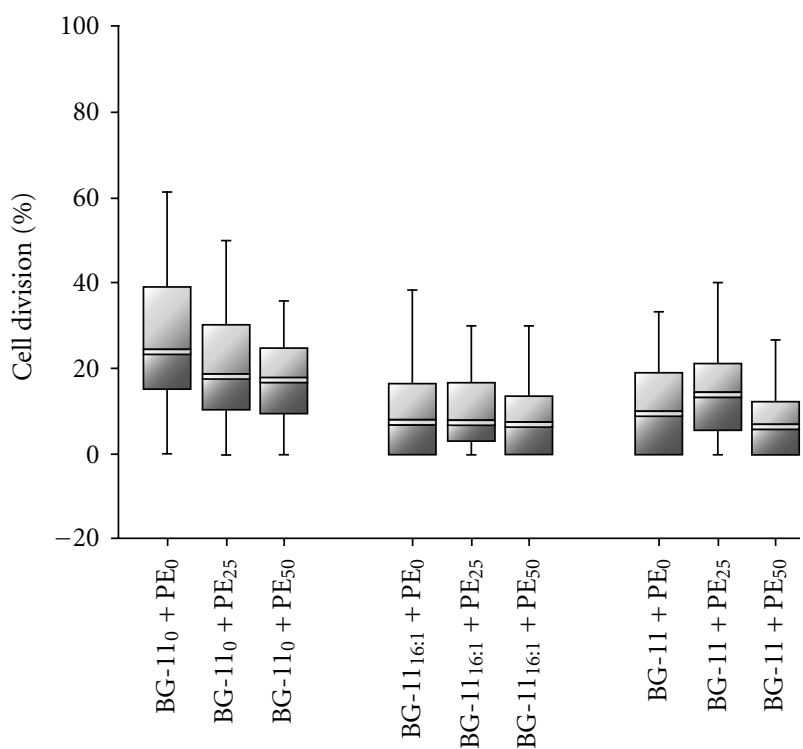

FIGURE 4: Percentage of dividing cells evaluated according to (1) in trichomes of $N$. sphaericum growing in each of the experimental conditions used in the study.

free-periphyton extract when the concentration of nitrogen was supplied excessively (BG-11 $\left.+\mathrm{PE}_{0}\right)$.

The cell length correlated $(P$ value $\leq 0.05)$ if the periphyton extract concentration was limited or oversupplied combined with the absence or with any concentration of

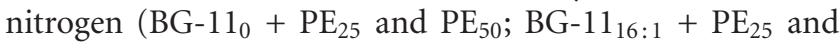
$\mathrm{PE}_{50} ; \mathrm{BG}-11+\mathrm{PE}_{25}$ and $\left.\mathrm{PE}_{50}\right)$. Figure 5 indicates that nitrogen moderately supplied or totally absent without or combined with moderate or oversupplied periphyton led to an increase in the length of the cells. In contrast, an excessive nitrogen supply maintained the cell length at a minimum, particularly when combined with an oversupply of periphyton extract.

3.4. Growth of Thalli of N. Sphaericum in Culture (Chlorophyll-a Concentration). As indicated in Figure 6, the thallus growth (chlorophyll- $a$ amount) shows significantly correlated interactions ( $P$ value $\leq 0.01)$ with all tested culture conditions for solid media, the two nitrogen concentrations solid media and the medium without nitrogen (BG-110, BG-11, and BG-11 16:1) as well as nitrogen-combinations in the three solid media with or without periphyton extract $\left(\mathrm{PE}_{0}, \mathrm{PE}_{25}\right.$, and $\left.\mathrm{PE}_{50}\right)$.

The results of the eighth week (Figure 6) showed the trend of an increasing biomass of the thalli by adding any of the extracts of periphyton $\left(\mathrm{PE}_{25}\right.$ and $\left.\mathrm{PE}_{50}\right)$ but only in the absence of nitrogen (BG-110). For the remaining experiments, we observed that by the addition of the periphyton extract the concentration of chlorophyll- $a$ showed the trend to decrease regardless of the biomass of the thalli and independent of the nitrogen.

\section{Discussion}

The periphyton from the EER wetlands can store large amounts of nutrients and so represents a good candidate for agroecological use. However, factors affecting its growth in situ were not well understood. For example, a species of the periphyton, N. sphaericum, does not grow at the same magnitude in the distinct ecosystems of these wetlands. The first hypothesis to be tested was that the size of trichomes was not related to the number of times at which the cells divide. This means that neither the nitrogen nor the accompanying cyanoprokaryotes stimulate the cell division and consequently the conspicuousness of the thalli observed in the field. This was verified by the attempt to correlate the cell size and cell division rate that turned out as statistically insignificant.

Through the study of N. sphaericum in cultures supported by the statistical verification, we have given experimental evidence that the length/width of the cells and the amount of chlorophyll- $a$ produced by the thallus are related to the concentration of nitrogen and the interaction of nitrogen with the presence of other cyanoprokaryotes represented by the periphyton extract. Hence these two variables may be interacting in the wetland to influence the size of the trichomes and thalli of N. sphaericum contributing to the observed growth differences between the two sites. 


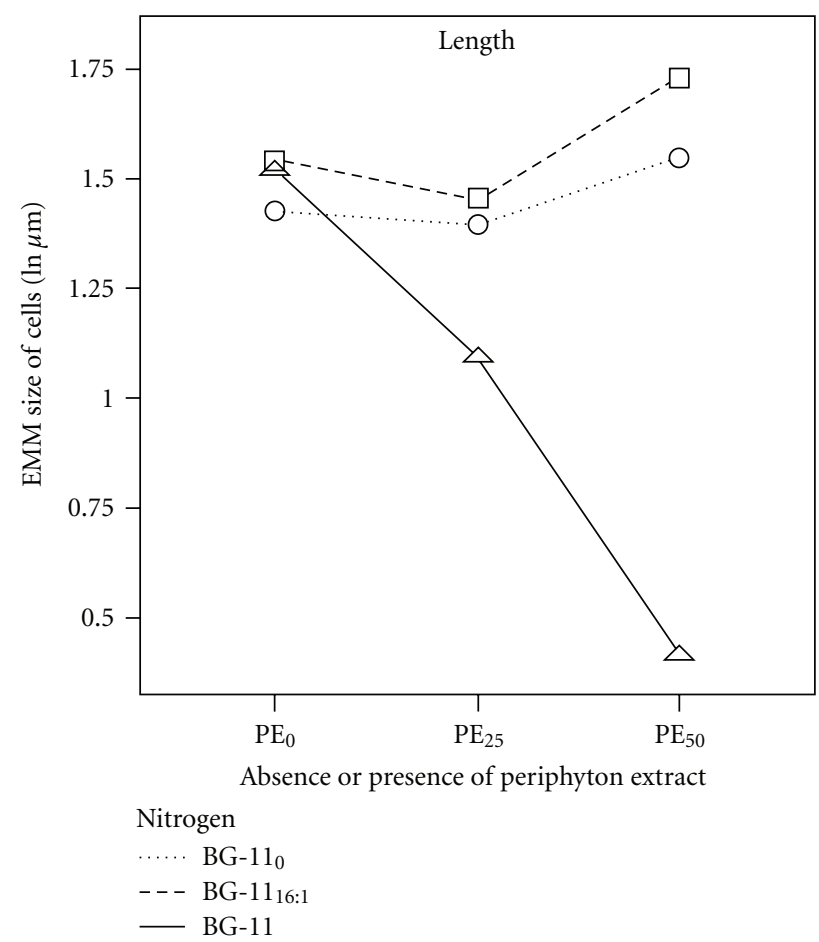

(a)

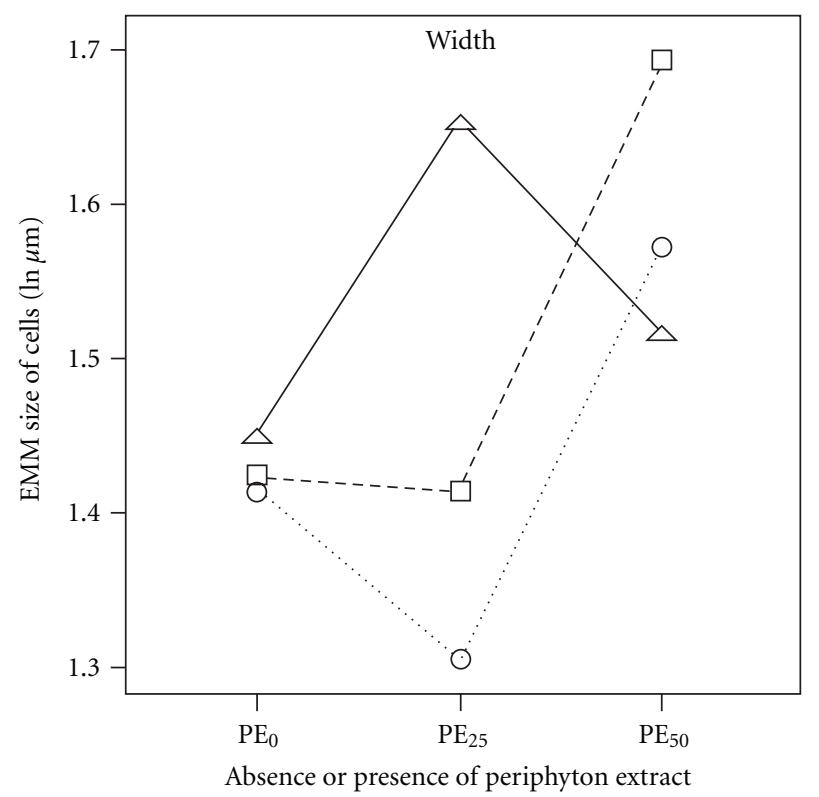

Nitrogen

…. BG- $11_{0}$

- - BG-11 16:1

- BG-11

FIgURE 5: Graphic profiles of estimated marginal means (EMMs) for data of the length and width of N. sphaericum cells. The differences plotted to support the proposed objectives for each experimental condition of nitrogen (solid or dotted lines) and extract periphyton ( $x$-axis) are statistically significant $(P \leq 0.05)$.
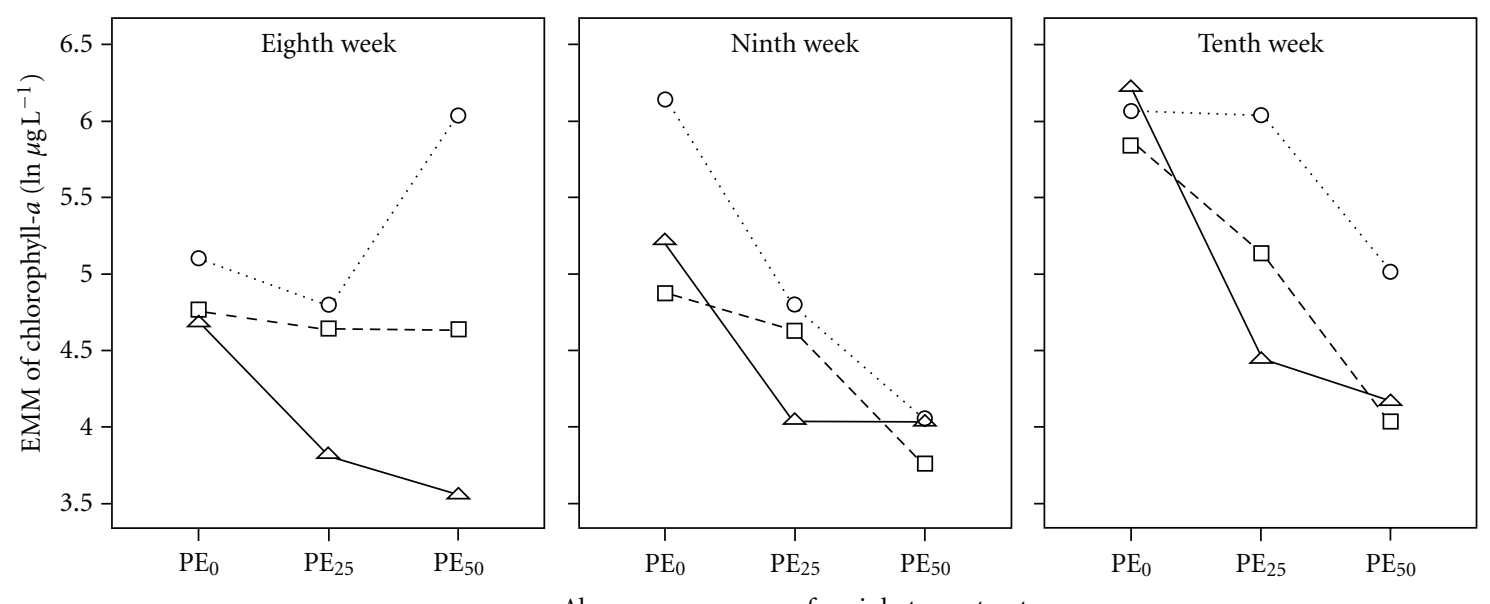

Absence or presence of periphyton extract
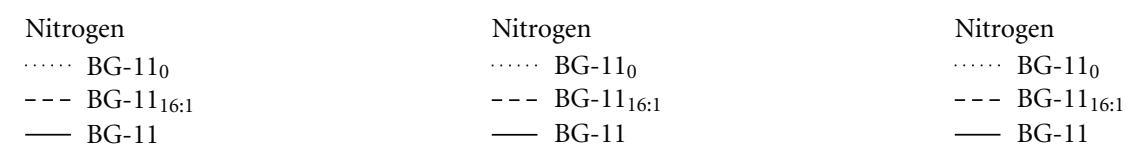

FIGURE 6: Graphic profiles of the estimated marginal means (EMMs) for data of chlorophyll- $a$ of $N$. sphaericum thalli. The differences plotted to support the proposed objectives for each experimental condition of nitrogen (solid or dotted lines) and periphyton extract ( $x$-axis) are statistically significant $(P \leq 0.05)$. 
As a result of the size of the trichomes it is suggested that the thalli vary in the way they are compacted. For example, when grown in BG-11 medium with a large amount of periphyton $\left(\mathrm{PE}_{50}\right)$, the cells are smaller, the trichomes are little entangled, and the thalli are less compact as if the thalli grow in a BG-11 $1_{0}$ medium with no periphyton extract $\left(\mathrm{PE}_{0}\right)$. Due to the size of the trichomes, the amount of chlorophyll- $a$ is less in the BG-11 medium as if grown in a BG-11 $1_{0}$ medium, especially when there is no periphyton extract present $\left(\mathrm{PE}_{0}\right)$. However, it is possible in the absence of nitrogen that the thalli grow well when periphyton is present $\left(\mathrm{PE}_{25}\right.$ and $\left.\mathrm{PE}_{50}\right)$.

These results demonstrate the multifactorial interaction between the variables instead of their isolated action giving rise to the growth difference between the thalli of N. sphaericum in cultures. These may be at the origin of the observed differences in situ. The periphyton may promote the growth of $N$. sphaericum but interferes with the nitrogen amount that builds up in the substrate. In this sense, it is maybe important to consider that the heterocytous Cyanoprokaryota can fix nitrogen. Nevertheless, the periphyton nitrogen fixation in the tufts is similar in the different places of the EER $[21,22]$. The heterolytic composition of the periphyton species in the rainforest could be indicative of a decreased diazotrophic growth of cyanobacteria in this ecosystem, where the other Nostocales can interfere compared to the same in the tropical deciduous forest [23]. Following our results, it is suggested that nitrogen fixation is not the limiting factor for the $N$. sphaericum growth but rather the excess nitrogen that accumulates in the soil. N. sphaericum competitively grows best in an environment in which the nitrogen is absent or moderate in the substrate and with few or no Nostocales such as in the tropical deciduous forest in the EER.

This work highlights the interaction of $N$. sphaericum growth with different concentrations of nitrogen and the presence of cyanobacteria in the substrate. Other factors as irradiation, temperature, and humidity were not considered as control variables for the experiments, mainly because, in the EER as in other ecosystems $[1,2,24-$ 27], Cyanoprokaryota may be tolerant to changes in light, temperature, or desiccation. Irradiation may be restricted, but only for short periods in the tropical deciduous forest due to the higher density and tallness of the vegetation surrounding the clearings [28]. Moreover, Nostocales species respond very quickly to extreme withering [25] particularly terrestrial species [26] and also respond to temperature variations by regulating the fatty acid composition [25]. Thus this factor variation in a range of $18^{\circ} \mathrm{C}$ and $30^{\circ} \mathrm{C}$ does not affect the growth of $N$. sphaericum. This capability could be shared in general by prokaryotes $[29,30]$. We also did not evaluate the relation between water supply and $N$. sphaericum growth. It was observed that the absence of the water column for 8 months in the EER did not limit this species to sprawl. It seems that akinetes fulfill the function of expansion of the thalli mainly in the dry season [8]. This role of akinetes is probably not unique to the studied species since it has been suggested that akinetes could have appeared early in the evolution as a dispersal response that conferred a significantly selective advantage, which may have been even greater than that of nitrogen fixation [24].

\section{Conclusion}

We have established the influence of nitrogen and the presence of other cyanoprokaryotes on the growth of $N$. sphaericum in cultures. Both factors could be responsible for the marked differences of the N. sphaericum growth in the EER wetlands. The relationship between nitrogen and periphyton on the growth of $N$. sphaericum will contribute to future studies assessing the potential use of periphyton as a natural fertilizer. This is of relevance because organic farming may contribute substantially to the future agricultural production worldwide by improving the soil quality and thereby reducing environmental impacts of conventional farming. Even if the yields may be less high than in systems receiving mineral fertilizers and herbicides, finally it must be decided on the tradeoff between productivity and environmental responsibility [31].

\section{Authors' Contribution}

RT: Design and parameters analysis; IB-A: Field work and experiments; RT, TB and CP: Analysis of results and discussion.

\section{Conflict of Interests}

The authors declare that they do not have any financial or personal relationship with other people or organizations that could inappropriately influence (bias) our work.

\section{Acknowledgments}

The authors are indebted to Josef Elster, Institute of Botany (Academy of Sciences CR) for his thoughtful suggestions that improved the manuscript. They also thank Eberto Novelo and Pilar Alonso, Facultad de Ciencias (UNAM) and Ana Luisa Anaya, Instituto de Ecología (UNAM) for their valuable suggestions to the manuscript. This work was supported by DGEP-UNAM and CONACyT (25264-N). The authors thank Guadalupe Vidal for the technical support and Concepción Celis for the proofreading of this manuscript.

\section{References}

[1] E. Novelo and R. Tavera, "The role of periphyton in the regulation and supply of nutrients in a wetland at El Eden, Quintana Roo," in The Lowland Maya Area: Three Millennia at the Human-Wildland Interface, A. Gómez-Pompa, S. Allen, A. M. Fedick, J. J. Jiménez-Osornio, and Q. Roo, Eds., pp. 217236, Haworth Press, New York, NY, USA, 2003.

[2] B. Morrison and R. Cozátl-Manzano, "The role of periphyton in the regulation and supply of nutrients in a wetland at El Eden," in The Lowland Maya Area: Three Millennia at the Human-Wildland Interface, A. Gómez-Pompa, S. Allen, A. M. Fedick, and J. J. Jiménez-Osornio, Eds., pp. 401-414, Haworth Press, New York, NY, USA, 2003.

[3] S. Palacios-Mayorga, A. L. Anaya, E. González-Velázquez, L. Huerta-Arcos, and A. Gómez-Pompa, "Periphyton as a potential biofertilizer in intensive agriculture of the ancient 
Maya," in Lowland Maya Area: Three Millennia at the HumanWildland Interface, pp. 389-400, Haworth Press, New York, NY, USA, 2003.

[4] S. L. Fedick, B. A. Morrison, B. J. Andersen, S. Boucher, J. Ceja-Acosta, and J. P. Mathews, "Wetland manipulation in the Yalahau region of the northern Maya lowlands," Journal of Field Archaeology, vol. 27, no. 2, pp. 131-152, 2000.

[5] A. Gómez-Pompa, M. F. Allen, S. L. Fedick, and J. J. JiménezOsornio, Eds., The Lowland MayaArea: Three Millennia at the Human-Wildland Interface, Haworth Press, New York, NY, USA, 2003.

[6] R. Tavera and E. Novelo, "El perifiton de los humedales de Yucatán y la cultura maya," Ciencias, vol. 102, pp. 40-45, 2011.

[7] E. Novelo, R. Tavera, and C. Ibarra, Bacillariophyceae From Karstic Wetlands in Mexico, vol. 54 of Bibliotheca Diatomologica, J. Cramer, Stuttgart, Germany, 2007.

[8] I. Becerra-Absalón and R. Tavera, "Life cycle of Nostoc sphaericum (Nostocales, Cyanoprokaryota) in tropical wetlands," Nova Hedwigia, vol. 88, no. 1-2, pp. 117-128, 2009.

[9] J. C. Meeks and J. Elhai, "Regulation of cellular differentiation in filamentous cyanobacteria in free-living and plant-associated symbiotic growth states," Microbiology and Molecular Biology Reviews, vol. 66, no. 1, pp. 94-121, 2002.

[10] T. Beach, N. Dunning, S. Luzzadder-Beach, and V. Scarborough, "Depression soils in the lowland tropics of Northwestern Belize: anthropogenic and natural origins," in The Lowland Maya Area: Three Millennia at the Human-Wildland Interface, pp. 139-174, Haworth Press, New York, NY, USA, 2003.

[11] E. Ceccon, I. Olmsted, C. Vázquez-Yanes, and J. Campo-Alves, "Vegetación y propiedades del suelo en dos bosques tropicales secos de diferente estado regeneracional en Yucatán," Agrocencia, vol. 36, no. 5, pp. 621-631, 2002.

[12] L. A. Martos, "La costa oriental de Quintana Roo," Arqueología Mexicana, vol. 9, no. 54, pp. 26-33, 2002.

[13] A. Pentecost and B. A. Whitton, "Limestones," in The Ecology of Cyanobacteria, B. A. Whitton and M. Potts, Eds., Chapter 9, pp. 257-279, Kluwer Academic, Dordrecht, The Netherlands, 2000.

[14] E. Rejmánková, J. Komárek, and J. Komárková, “Cyanobacteria-a neglected component of biodiversity: patterns of species diversity in inland marshes of northern Belize (Central America)," Diversity and Distributions, vol. 10, no. 3, pp. 189199, 2004

[15] Cyanosite, 2012, http://www-cyanosite.bio.purdue.edu/.

[16] United States Environmental Protection Agency, 2010, http:// www.epa.gov/nerlewww/marinmet.htm.

[17] M. H. Zwietering, I. Jongenburger, F. M. Rombouts, and K. Van't Riet, "Modeling of the bacterial growth curve," Applied and Environmental Microbiology, vol. 56, no. 6, pp. 1875-1881, 1990.

[18] R. Rippka, J. Deruelles, and J. B. Waterbury, "Generic assignments, strain histories and properties of pure cultures of cyanobacteria," Journal of General Microbiology, vol. 111, no. 1, pp. 1-61, 1979.

[19] H. Hillebrand and U. Sommer, "The nutrient stoichiometry of benthic microalgal growth: redfield proportions are optimal," Limnology and Oceanography, vol. 44, no. 2, pp. 440-446, 1999.

[20] C. S. Reynolds, The Ecology of Freshwater Phytoplankton, Cambridge University Press, London, UK, 1984.

[21] R. Vargas and E. Novelo, "Fijación de nitrógeno por Cyanoprokaryota en la Reserva Ecológica El Edén, Q.R., México," Mexican Studies/Estudios Mexicanos, vol. 19, no. 2, pp. 277-285, 2003.
[22] R. Vargas and E. Novelo, "Seasonal changes in periphyton nitrogen fixation in a protected tropical wetland," Biology and Fertility of Soils, vol. 43, no. 3, pp. 367-372, 2007.

[23] L. J. Stal, "Cyanobacterial mats and stromatolites," in The Ecology of Cyanobacteria. Their Diversity in Time and Space, B. A. Whitton and M. Potts, Eds., pp. 61-120, Kluwer Academic, Dodrecht, The Netherlands, 2000.

[24] M. Potts, "Nostoc," in The Ecology of Cyanobacteria, B. A. Whitton and M. Potts, Eds., Chapter 17, pp. 465-504, Kluwer Academic, Dordrecht, The Netherlands, 2000.

[25] S. Scherer and Z. P. Zhong, "Desiccation independence of terrestrial Nostoc commune ecotypes (cyanobacteria)," Microbial Ecology, vol. 22, no. 1, pp. 271-283, 1991.

[26] S. Chintalapati, J. S. S. Prakash, A. K. Singh et al., "Desaturase genes in a psychrotolerant Nostoc sp. are constitutively expressed at low temperature," Biochemical and Biophysical Research Communications, vol. 362, no. 1, pp. 81-87, 2007.

[27] J. Kvíderová, J. Elster, and M. Šimek, "In situ response of Nostoc commune s.l. colonies to desiccation in Central Svalbard, Norwegian High Arctic," Fottea, vol. 11, no. 1, pp. 87-97, 2011.

[28] G. Schultz, "Structure and diversity of the forests at EER Ecological Reserve," in Lowland MayaArea: Three Millennia at the Human-Wildland Interface, A. Gómez-Pompa, A. M. Allen, S. Fedick, and J. J. Jiménez-Osornio, Eds., pp. 91-114, Haworth Press, New York, NY, USA, 2003.

[29] E. Helmke and H. Weyland, "Psychrophilic versus psychrotolerant bacteria occurrence and significance in polar and temperate marine habitats," Cellular and Molecular Biology, vol. 50, no. 5, pp. 553-561, 2004.

[30] T. L. Nadeau and R. W. Castenholz, "Characterization of psychrophilic oscillatorians (cyanobacteria) from antarctic meltwater ponds," Journal of Phycology, vol. 36, no. 5, pp. 914923, 2000.

[31] K. Birkhofer, T. M. Bezemer, J. Bloem et al., "Long-term organic farming fosters below and aboveground biota: Implications for soil quality, biological control and productivity," Soil Biology and Biochemistry, vol. 40, no. 9, pp. 2297-2308, 2008. 

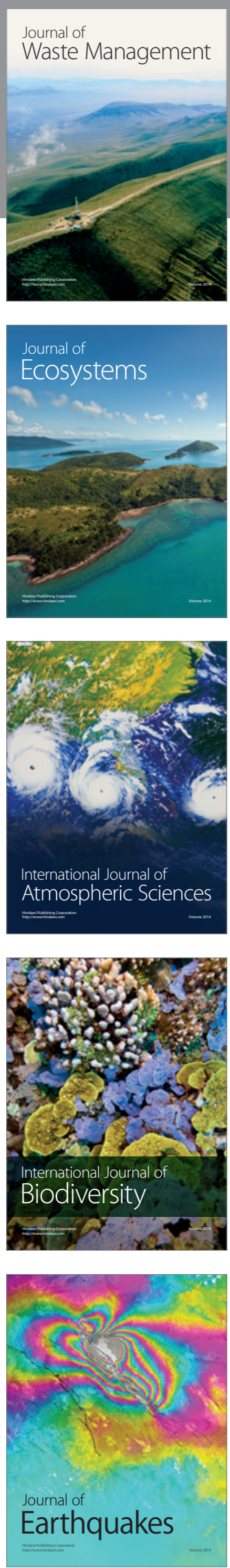
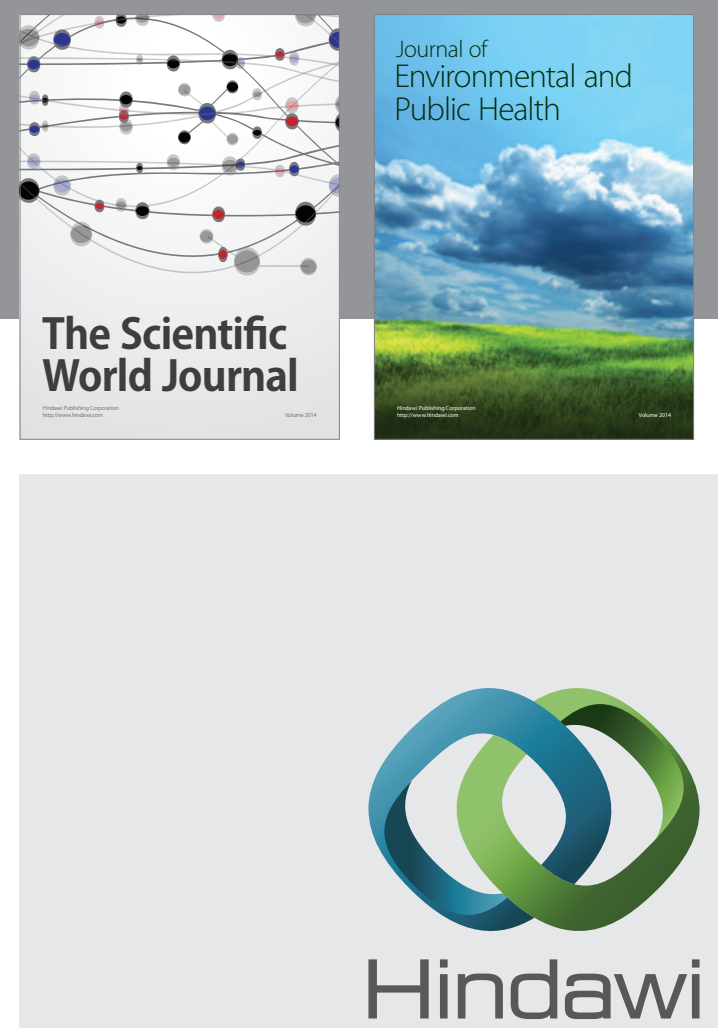

Submit your manuscripts at

http://www.hindawi.com
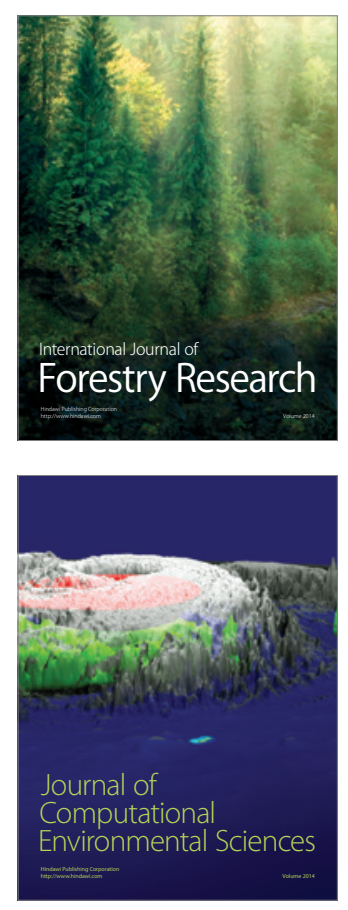
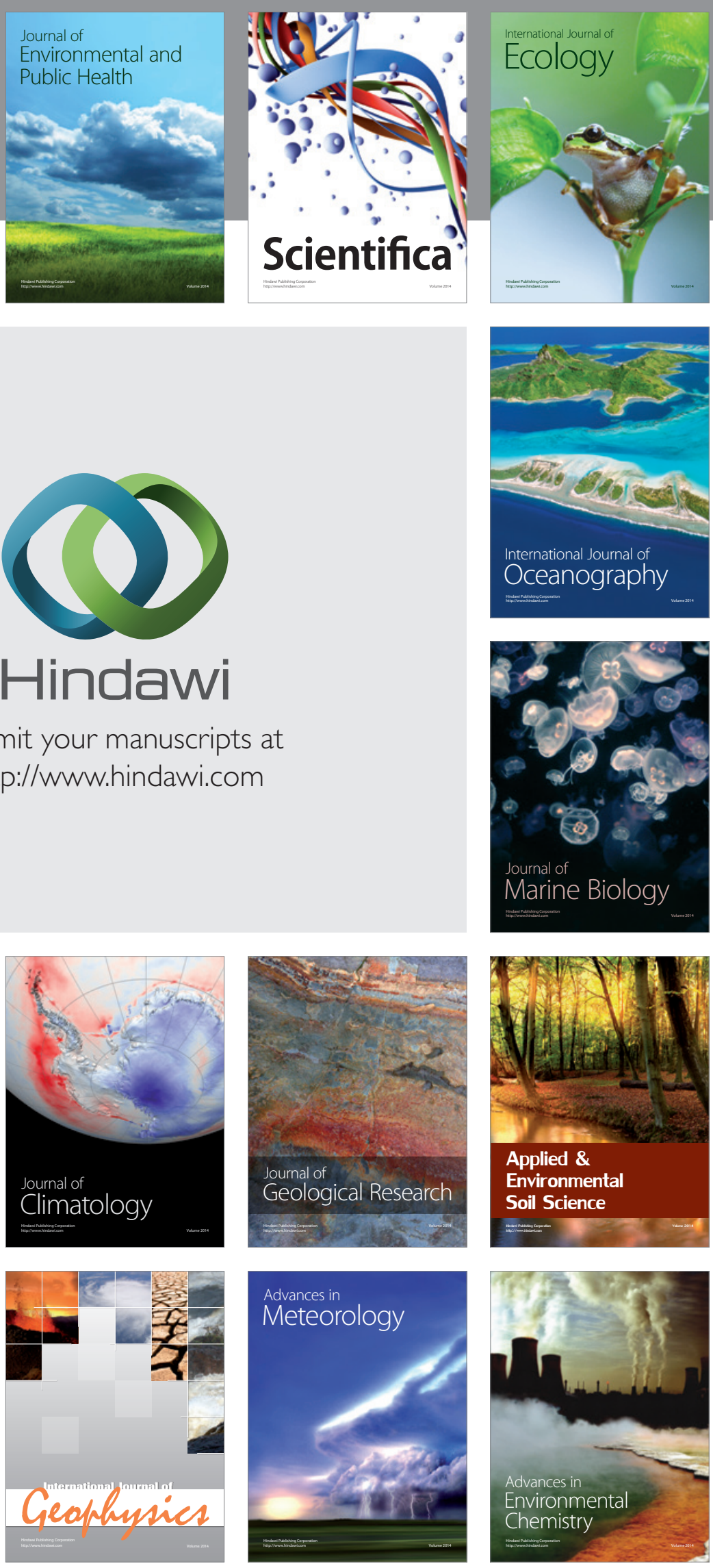